\title{
Differentiation of the Legal Regulation of the Loan Treaty by Prerevolutionary and Soviet Legislation
}

\author{
Kamil M. Arslanov, Artur I. Khabirov
}

\begin{abstract}
One of the trends in the modern development of legal thought in Russia should be called an appeal to the experience of past generations. A loan agreement is one of the oldest institutions known as far as Roman law [1, 18]. A detailed regulation of legal regulation in the Russian Empire was obtained by the loan agreement in the book of the fourth volume $X$ of part 1 of the Code of laws of the Russian Empire (hereinafter - the Code of Laws). The rules contained in the said act were valid until the October Revolution of 1917. At the end of the XIX beginning of the XX centuries. The highest established Drafting Commission developed the Civil Code Draft (hereinafter - the draft GU), the fifth chapter of the second volume of the second book of which was devoted to the regulation of the loan agreement (Articles 348-363). In the Soviet period, for the first time, a loan agreement was regulated by the Civil Code of the RSFSR of 1922 (hereinafter - the Civil Code of the RSFSR) in chapter VI "Loan". It is of great theoretical and practical interest to compare the rules for regulating a loan agreement in the pre-revolutionary and Soviet periods for several reasons. Firstly, "Russian private law is at the stage of its reform" [2, 126]. Secondly, the text of the 2009 Concept states that the historical development of Russian law and the legal systems of continental law (Roman law) should be taken into account. In the article, the authors study the historical legal tradition of a loan obligation.
\end{abstract}

Keywords: civil law, loan agreement, Civil Code of the Russian Federation, history, Code of laws of the Russian Empire.

\section{INTRODUCTION}

"Recently, interest in history has been reviving as an instrument of cognition, development, and reform of existing law. The attitude of lawyers to the law as to the law of "today", when it is perceived as unrelated to past legal studies, is becoming a thing of the past" $[3,204]$. The concept recognized as a priority the appeal to the history and legal traditions of the past. However, it is not enough to indicate the beginning of Russian law in the 19th century; it is still necessary to link the current legal regulation with the past.

\section{METHODS}

The study is based on a method of analysis of current Russian legislation and law enforcement practice and existing European (world) standards for the purpose of legal unification [4, 386]. The methods of legal modeling and forecasting make it possible to determine the need to amend

Revised Manuscript Received on November 08, 2019.

* Correspondence Author

Kamil M. Arslanov, Kazan Federal University

Artur I. Khabirov, Kazan Federal University existing Russian regulations, as well as the need to adjust judicial practice [5]. Thanks to the use of modeling and forecasting methods, the consequences of such changes and adjustments can be ascertained with a sufficient degree of certainty, and it will also be revealed how, ultimately, Russian law enforcement practice will be close to existing European (world) standards [6, 324]. The sociological method allows the assessment of social problems from a legal position, from the perspective of a legislator and law enforcer [7, 651]. The interpretation method complements the comparative legal analysis in the study, allowing you to understand and compare Russian and European (world) legal standards [8, 62]. The use of various methods made it possible to formulate the main theoretical conclusions and make their own proposals on the studied sphere of public relations $[9,421]$.

\section{RESULTS AND DISCUSSION}

It should be noted that the loan rules of the pre-revolutionary and Soviet periods have much in common. According to pre-revolutionary legislation, "a loan is a contract under which a lender lends his capital to a person, free of charge or for a certain percentage interest, to another person - a debtor who is obliged to return the borrowed money with the growth agreed upon for using the capital"1. By definition, given in Art. 348 of the GU Project, "under the loan agreement, the lender transfers to the borrower, for a fee (growth, interest) or free of charge, a certain amount of money, and the borrower undertakes to return to the lender an equal amount of money at the time designated by the contract or on demand of the lender"2. Article 208 of the Civil Code of the RSFSR defined a loan agreement as an agreement according to which one party transfers money or things determined by generic characteristics to the other side (borrower), and the borrower undertakes to return to the lender the amount of money received or equal to the borrowed amount of things of the same kind and quality with interest or without interest. In the indicated historical periods, the signs of the loan agreement did not differ either: a real, unilaterally binding agreement, which can be either onerous or gratuitous. However, even in the pre-revolutionary period D.I. Meyer determined that "a loan is such an agreement of the will of two persons, according to which the lender undertakes to provide the other with ownership of any object, determined by measure, weight or score; and another person, the borrower, within a certain period of time - to return to him the same subject of the same quality and in the same quantity" $[10,15]$. In modern doctrine should highlight the works of a 
large circle of scientists, civilists, defending the views of D.I. Meyer. For example, Yu.V. Romanets writes that a professional lender may have an obligation to issue a loan, a loan [11, 8-18]. A.G. Karapetov and A.I. Saveliev points out that the loan agreement, built by the parties according to the consensual model, is extremely close in its economic and legal nature to the real loan agreement provided for by law and "... there are no substantial grounds for refusing to recognize such an agreement valid from the moment of conclusion of the agreement obliging the lender to provide a loan" $[12,79]$.

Returning to a comparison of the rules of law of the pre-revolutionary and post-revolutionary periods with the modern legal regulation of the loan agreement, we note that article 2014 of the Code of Laws established that "a loan shall be considered null and void if it is found by judicial examination that it is non-monetary"3. In Art. 361 of the GU Project, the rule was established that "the dispute that the money was not transferred or transferred in smaller amounts against the loan shown in the act (the dispute about non-cash)

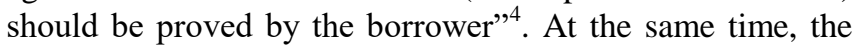
RSFSR Civil Code contained detailed regulation on this issue: "The borrower has the right to challenge the validity of the loan agreement in whole or in part regarding its non-cash (non-currency), proving that money, things or their property equivalent (Article 209 of the RSFSR Civil Code) in reality they were either not received at all from the lender, or received in an amount less than that shown in the contract. In cases where a loan agreement must be made in writing, contesting it by testimony is not allowed, except in cases of criminal offenses (Article 217 of the Civil Code of the RSFSR)"5. Thus, using the example of norms on the grounds and procedure for contesting a loan agreement for its non-monetary resources, one can trace the progressive development of Russian law. The current regulation of contesting a loan agreement on its non-monetary terms, both textually and meaningfully, is closest to the Soviet period.

It is also indicative that the loan agreement is universal, suprainstitutional in nature by laws of various periods. According to the rules of Article 2045 of the Code of Laws, "debt obligations made at home are bills signed by the debtor in amounts following the work, service, seized items or goods, etc.". According to Art. 2017 of the Code of Laws were not considered "non-monetary borrowed letters issued instead of cash payments for work, services, goods and products, also in satisfaction of penalties arising from contracts" $"$. And article 2046 of the Code of Laws established that if such an invoice was not presented for payment within six months, it should be turned into a loan obligation ${ }^{7}$, i.e. any debt, regardless of the reason for its occurrence, by agreement of the parties or by virtue of an indication of the law was transformed into a loan obligation. About this D.I. Meyer wrote that "the law allows the issuance of a loan letter and regardless of the loan, for example, instead of paying the account, although the debt on the account does not indicate that the debtor borrowed such an amount from the attorney, but that the debtor took it from the attorney goods for such an amount" [10]. Similar provisions were contained in article 350 of the draft GU "Loan rules apply to the case when a loan certificate is issued as proof of debt arising from sale, lease or other grounds" ${ }^{\text {. }}$. Article 209 of the Civil Code of the RSFSR established that "the parties may put into debt form any debt arising from the sale of property, rental of property or other grounds. In this case, the loan rules apply". Article 818 of the Civil Code of the Russian Federation fully repeats the rules of the pre-revolutionary and post-revolutionary periods.

Similar legal regulation can be traced in relation to the form of the loan agreement. Thus, article 2032 of the Code of Laws of the Russian Empire allowed the conclusion of a loan agreement orally. Article 349 of the Draft Civil Code contained a rule according to which "a loan worth more than thirty rubles must be certified by a loan letter, receipt or other written act" $"$. True, the consequences of non-observance of the written form differ: according to pre-revolutionary law, the debtor, even having proved the validity of the loan, could not receive the entire loan amount, but only within 12 rubles this is the maximum amount for oral loans in the pre-revolutionary era. The provisions of the Civil Code of the RSFSR on the question of the form of the loan stipulated that a loan agreement worth more than 50 gold rubles should be made in writing under pain of consequences provided for in the note to Article 136 of the Civil Code of the RSFSR, namely, non-compliance with the rule set forth in this article, deprived the parties of the right, in the event of a dispute, to invoke evidence in support of the contract, but did not deprive them of the right to provide written evidence. Similar rules are provided for under current law in Art. 808 and 162 of the Civil Code of the Russian Federation. Thus, the progressive development of law is traced in relation to the consequences of non-compliance with the written form of the transaction.

The rule about the possibility of concluding a preliminary agreement on concluding a loan agreement in the future is also indicative. According to the provisions of Article 362 of the GU Project "the obligation to give a loan established in the preliminary contract loses its force if it subsequently occurs or becomes known for the first time to a person who undertakes to give a loan, circumstances that so significantly worsen the property situation of the other party, that there is a danger of losing the entire amount intended for the transfer loan or part thereof. A preliminary loan agreement must be certified by letter" ${ }^{\prime 10}$. In accordance with Art. 218 and 219 of the Civil Code of the RSFSR "a preliminary agreement on the conclusion of a future loan agreement must be made in writing, regardless of the amount of the loan. And a person who undertakes to give another loan under a preliminary agreement may demand termination of the preliminary agreement if subsequently the property position of the counterparty worsens significantly, in particular if it is declared insolvent or suspends payment" $"$.

At the same time, in the current Civil Code of the Russian Federation, chapter 42, devoted to the regulation of a loan agreement, does not contain an indication of the consequences of concluding a preliminary loan agreement. It does not give an unambiguous answer about the possibility and legal fate of concluding preliminary agreements with 
respect to real agreements Art. 429 of the Civil Code of the Russian Federation. According to the views of civilian scientists of both the modern and past periods, in the event of a preliminary agreement on the transfer of the subject of the loan in the future, the lender has an obligation to conclude a loan agreement on agreed terms $[13,18]$. Consequently, the conclusion of a loan agreement is divided into two stages: the first is the achievement of an agreement; the second is the transfer of the thing, in addition, the loan agreement in this case clearly becomes bilaterally binding, and the legal relationship between the lender and the borrower will arise even before the transfer of the thing [14, 16,17]. Even an appeal to most legislative acts of foreign countries of that period, for example, to Swiss, French, Italian or Saxon legislation, does not provide an answer to the question posed. Indeed, for consensual agreements, such a question cannot be significant, because the preliminary contract is essentially the main contract and is of final importance to the parties (see, for example, clause 5. article 429 of the Civil Code of the Russian Federation). Foreign legislation of the late XIX - early XX centuries recognized an agreement on a future loan valid if the amount or number of loan items was determined in such an agreement (Zurich - Art. 1109 - and Saxon Code - Art. 1068, Baltic Civil Laws - Art. 3642). Also, the drafters of the GU Project noted that a person who agreed to accept an interest-free loan in the future has the right to refuse to receive a loan. If the loan was supposed to be interest-bearing, then the refusal should entail property liability of the person who accepted the promise ${ }^{12}$.

\section{IV.SUMMARY}

On the example of the above rules governing the loan agreement in the pre-revolutionary and post-revolutionary period and their comparison with modern regulation, we consider it proved that the modern legal regulation of the loan agreement is based on the norms of the Russian pre-revolutionary legislation and the pre-revolutionary doctrine, as well as the norms of the post-revolutionary period, which allows the use of legal designs developed during these periods by science and practice. In particular, the pre-revolutionary doctrine proved the possibility of concluding a loan agreement according to the consensual model, and therefore we believe that the dissemination of this legal structure in modern legislation from June 1, 2018 is justified. As a result, we consider it possible to propose the following changes in Sec. 42 of the Civil Code of the Russian Federation, subject to amendments made by federal law of July 26, 2017 No. 212-FL, which entered into force on June $01,2018^{13}: 1$. Paragraph 2 of paragraph 1 of Article 807 of the Civil Code of the Russian Federation shall be reworded as follows: "Loan agreement, in which the lender (the lender) is a citizen who is not an individual entrepreneur, and whose subject matter is money, is considered to be concluded from the moment the money is transferred".

\section{CONCLUSIONS}

Since the current Russian legislation does not contain rules directly regulating the legal relations between the parties when concluding a preliminary agreement on concluding a loan agreement in the future, as well as on the consequences of failure to fulfill such an agreement, we believe that the rules developed by the pre-revolutionary doctrine, the Civil Code of the Russian Empire, and the Civil Code should be applied RSFSR 1922. Namely: firstly, it should be legally allowed to conclude preliminary agreements on concluding a loan agreement in the future. Secondly, to establish that the preliminary agreement on the conclusion of a future loan agreement must be made in writing, regardless of the amount of the loan. Thirdly, to stipulate that a person who undertakes to loan to another under a preliminary agreement may demand termination of the preliminary agreement if circumstances that so significantly worsen the property of the other party are subsequently entered or made known to the person for the first time that there is a danger of losing the whole item, the amount intended to be given back on loan or their part. Fourth, in the case of the refusal of the person who promised to lend from the performance of his duty, he had to compensate the other party for the losses incurred by it. In turn, the one to whom the loan was promised, in case of refusal to accept the loan amount, should have compensated the other party for losses only if the loan agreement was supposed to be onerous (interest).

In connection with the above, we propose to supplement article 807 of the Civil Code of the Russian Federation with paragraph 5 of the following content:

"The parties are entitled to conclude a preliminary agreement on concluding a loan agreement in the future.

The obligation to give a loan established in the preliminary contract becomes void if, subsequently, or for the first time becomes known to a person who undertakes to give a loan, circumstances so significantly worsening the property situation of the other party, that there is a danger of losing the entire amount intended to be given on loan or part of it.

If the person who pledged to lend did not fulfill his duty, then he had to reimburse the other party for its losses. If a person who has undertaken the obligation to accept the subject of the loan specified in the preliminary agreement refuses to accept it, he is obliged to compensate the other party for losses only if the loan agreement was assumed to be onerous (interest)." And, finally, we propose article 808 of the Civil Code of the Russian Federation to be supplemented with paragraph three of the following content: "A preliminary agreement on the conclusion of a loan agreement in the future must be made in writing, regardless of the amount of the loan".

\section{ACKNOWLEDGEMENTS}

The work is performed according to the Russian Government Program of Competitive Growth of Kazan Federal University.

\section{REFERENCES}

1. Khabirov A.I. The system of rights and obligations of the parties to a loan obligation in modern law // Law and Management. XXI Century. 2019. -- P. 18-24

2. Arslanov K. M. On the importance of comparative legal studies of foreign law for the development of Russian private law // Comparative Law in the Integration of States: Proceedings of the II International Congress of Comparative Law (Moscow, December 3, 2012) / ch. ed. Yu.A. Tikhomirov, V.I. Lafitsky.

- M.: Institute of Legislation and Comparative Law under the Government of the Russian 
Federation: INFRA-M, 2013. - P. 126-131.

3. Arslanov K.M. The formation of the Kazan School of Civil Law and its impact on the development of modern Russian civil law / Kazan Law Schools: the evolution of educational and scientific traditions in modern jurisprudence. - M., 2016. -- P. 204-217.

4. Comparative Law. An Introduction to the Comparative Method of Legal Study and Research. By Gutteridge H. C., K.C., LL.D. (Cambridge Studies in International and Comparative Law, Vol. I.) London: Cambridge University Press. The Cambridge Law Journal. 1947. - 9 (3). - P. 386 - 387.

5. Dale, William. Legislative Drafting: A New Approach: a Comparative Study of Methods in France, Germany, Sweden and the United Kingdom. - London: Butterworths, 1977. -- 341 p.

6. Arslanov K.M., Khabirov A.I. About the Weak Party of the Loan Contract // Astra Salvensis, Review of History and Culture Supplement. - 2017. -- P.323-330.

7. Siems, M., \& Mac Síthigh, D. Mapping legal research. The Cambridge Law Journal. - 2012. -- 71 (3). - P.651 - 676.

8. Davies, P. Rectification versus interpretation: the nature and scope of the equitable jurisdiction. - The Cambridge Law Journal. - 2016. -- 75 (1). - P.62-85

9. Khabirov A.I., Khamitova G.M. On The Issue of the Place of a Loan Commitment in the System of the Russian Law of Obligations // The Journal of Social Sciences Research. 2018. - Special Issue - 5. - P. 421-424.

10. Meyer D. I. Russian civil law [Electronic resource]: 2 Parts, 2003. URL: http://civil.consultant.ru/elib/books/45/page_67.html (accessed: 05/12/2019)

11. Romanets Yu. V. System of contracts in the civil law of Russia / Yu. V. Romanets. - 2nd ed., Revised. and add. - M.: Norma: Infra-M, 2013. -496 p.

12. Karapetov A.G. Freedom of contract and its limits. T. 2: The limits of freedom to determine the terms of the contract in foreign and Russian law / A.G. Karapetov, A.I. Savelyev. - M.: Statute, 2012. -- 453 p.

13. Arslanov K.M. On the bilaterally binding nature of the loan agreement // Seventh Perm Congress of Legal Scientists: All-Russian materials. scientific-practical conf. Perm, 2016.P. 85-87.

14. Braginsky M.I. Contract Law / M.I. Braginsky, V.V. Vitryansky. Prince 5, t. 1: Loan, bank loan and factoring agreements. Agreements aimed at creating collective entities. - M.: Statute, 2006. -- 734 p.

15. Rasooli, M., \& Abedini, M. The Relationship between Organizational Support and Job Satisfaction of Experts and Managers of Islamic Azad University of Qeshm and Subsidiaries (International Units, Medical, Sama, Hormuz and Khamir). Dutch Journal of Finance and Management, 1(2), (2017).42. https://doi.org/10.29333/djfm/5818

16. Gamarra, M., Zurek, E., \& San-Juan, H. Addendum for: A Study of Image Analysis Algorithms for Segmentation, Feature Extraction and Classification of Cells. Journal of Information Systems Engineering \& Management, 3(1), (2018).05

17. García-Santillán, A. An Algorithm to Renegotiate Debt through Equivalent Equations and Transaction Costs: A Proposal for the Field of Financial Education. International Electronic Journal of Mathematics Education, 14(1), (2019). 123-136. https://doi.org/10.12973/iejme/3981

18. Novikova, I. N., Popova, L. G., Shatilova, L. M., Biryukova, E. V., Guseva, A. E., \& Khukhuni, G. T. Lexical and semantic representation of the linguistic and cultural concept "Rest" in the English, German, and Russian languages. Opción, 34(85-2), (2018). 237-256 